\title{
Случай на слухово-речева рехабилитация при пациент с постлингвална глухота след кохлеарна имплантация
}

\author{
Ф. Михайлова, А. Бачовска, П. Руев \\ МБАЛ „Тракия“, гр. Стара Загора
}

\section{Резюме}

Слуховата загуба е едно от най-честите сензорни нарушения, а с напредване на възрастта приблизително един на всеки трети на възраст над 65 години има социално значимо намаление на слуха. Кохлеарната имплантация както при деца, така и при възрастни, дава големи възможности за компенсация на слуховото увреждане.

Целта на настоящата разработка е да се представят резултатите и срещаните трудности от постоперативната слухово-речева рехабилитация при възрастен пациент с постлингвална глухота.

В заключение искаме да подчертаем важната роля на семейството в рехабилитационния процес и необходимостта от психологическа подкрепа.

\section{Увод}

Увреждането на слуха е едно от най-честите сензорни нарушения и засяга $1 \div 4 / 1000$ новородени, a c напредване на възрастта приблизително един на всеки трети между $65 \div 70$ години индивид има намаление на слуха [1]. Кохлеарната имплантация както при деца, така и при лица в активна възраст с тежко увреждане на слуха до степен на практическа глухота дава големи възможности за компенсация на слуховото нарушение.

Значението на слуха в ежедневието е огромно и проблемът за загубата му става все по-важен в практиката на оториноларинголога. По данни на различни източници през 70-те години на XX век лицата със слухови нарушения в процентно отношение са били $4 \div 6 \%$. По прогнозни данни на СЗО обаче през 2020 година в световен мащаб числеността на лицата със слухови нарушения ще нарасне до $30 \%$. Известно е, че намалението или загубата на слуха при възрастни пациенти води не само до драстични промени в комуникацията, но и до намаление на работоспособността и сериозни изменения в психоемоционалната сфера. Слуховото възприятие като цяло е много важно за психичното и личностовото развитие на човека и уменията му за общуване, без да ги предопределя изцяло. В тази връзка ролята на слуха не би трябвало да се разглежда сама по себе си, а в контекста на цялостното състояние на отделната личност. Както пише В. Кацарска, „Човекът е 
единна система и това означава, че слуховата система е само част от нея“" [2].

Целта на настоящото изследване е да се представят резултатите и срещаните трудности при постоперативната слухово-речева рехабилитация при пациент в зряла възраст след кохлеарна имплантация, като се отчита ролята на семейството и необходимостта от психологическа подкрепа.

\section{Клиничен случай}

Kacae се за пациент на възраст 60 години с прогресивно намаление на слуха от около $10 \div 15$ години и слухопротезиран многократно за този период. Независимо от адекватните настройки на слуховия апарат, поставен на по-добре чуващото ухо, и преждевременната му смяна (на 3та година от експлоатацията) пациентьт остава с незадоволителен социален контакт. Отказва да носи активно слуховият апарат, което налага извършване на кохлеарна имплантация на 16.03.2013 година със SONATA ti100 и стандартен електрод. След гладък постоперативен период кохлеарният имплант бе включен на 12.04.2013 година. В този най-ранен период пациентът съобщава за комфорт при чуването на звуци от околната среда, но с невъзможност за разбиране на реч. След аудиометрия в свободно звуково поле бяха проведени допълнителни настройки на речевия процесор, което доведе до разграничаване на отделните гласове и по-добро разбиране на речта. Отделните програми бяха адаптирани съобразно отговорите на пациента, като при програмирането се цели достигане на оптимално акустично равнище за всеки един от електродите.

\section{Методи}

При постлингвистичните деца и при възрастни с речеви опит езиковата система и уменията за слухово-речеви анализ вече са сформирани. Постоперативната слухово-речева рехабилитация е насочена към възстановяване на уменията за разбиране на речта и идентифициране на звуци от околната действителност с помощта на кохлеарния имплант.

По правило след около месец, при интензивна слухово-речева рехабилитация, късно оглушалите постлингвистични пациенти разбират речта в голям процент от комуникативните ситуации. В същото време продължават да отчитат по устните, особено в случаите, когато разговорът излезе извън конкретната комуникативна ситуация.

Основно се работи в следните направления [3]:

1. слухово възприемане на речеви единици;

2. локализация на източника на звук;

3. разпознаване на звуци от околната действителност;

4. разпознаване на думи с различен брой срички, произнесени по различен начин - бързо, шепнешком, на разстояние;

5. разпознаване на рядко използвани думи, произнесени изолирано и в изречение;

6. изречения с разбъркан словоред;

7. умение за възприемане на прозодическата страна на речта (интонация, смислово ударение, емоционална окраска, индивидуални особености на гласа, разпознаване на мъжки, женски и детски глас);

8. разпознаване на думи с еднакъв и различен брой срички при наличие на фонов шум;

9. възприемане на реч при общуване с няколко говорещи;

10. възприемане на реч по телефон;

11. възприемане на музика и телевизия.

Възможността за възприемане на речта при тези пациенти не се извършва само по време на занятията, а основно във всекидневното спонтанно общуване.

\section{Резултати и обсьждане}

След преминаване на първоначалната еуфория при поставяне на кохлеарния имплант и последващо включване на процесора при така представеният пациент започва същинската работа. Слухово-речевата рехабилитация се провежда веднъж или два пъти седмично с удължена продължителност на сесиите. Първата отчетена промяна се наблюдава в поведението на пациента. Проблемите със съня, наблюдавани през последните години, постепенно отшумяват. Тревожността и усещането за чуждо присъствие в случаите, когато е сам, значително намаляват.

Пациентът споделя, че чува, но много по-различно от очакваното. Определя го по следния начин: „Няма нищо общо с това, което помня. Чувам, но нищо не разбирам“. Звуците от околната действителност, не отговарят на реалните, гласовете на хората били монотонни, не може да 
се посочи посоката, от която идват, или конкретният говорещ. Пациентът се опитва да асоциира звуци с предмети или животни, но без успех към момента. Високочестотните звуци го дразнят, до степен да изключва импланта за известен период. Споделя, че тишината му липсва и това води до страх и нежелание да използва импланта. Работата продължава не в посока постановка на отделни звукове, а споделяне на усещания, преживявания, срещани трудности и страхове. Постигнатите резултати, проследявани в продължение на една година, по всяко едно от 11 направления, изброени по-горе, са следните:

- след направени първи настройки на речевия процесор говорът осезаемо става по-силен, отколкото преди операцията;

- разпознаването на отделните звукове, срички и думи е затруднено;

- пациентът споделя, че чува основно част от гласните звукове, а фоновият шум звучи като „лек ветрец“;

- наблюдава се бърза уморяемост, което води до увеличаване на грешките и отказ от провеждане на упражнения;

- при промяна на темата на разговора или закриване на устните с цел да се ограничи възможността за отчитане отговорите стават неадекватни;

- присъствието на повече от един участник в разговора кара пациента се дистанцира;

- отказва ползването на телефон, не слуша музика и разчита основно на отчитането от устните при разговор.

Поради пропуснати часове по слухово-речева рехабилитация и страх от смяна на програмите чуването и разбирането видимо са влошени. При преминаване на последна програма от първите настройки говорът става тих и леко неразбираем, а желанието за изолация и бързата уморяемост се засилват. Фоновият шум се определя като много по-силен, а раздразненията са по-чести.

След два месеца се направихаповторни настройки на процесора. Видима разлика според пациента през пьрвата седмица не се наблюдава. Това го кара да търси извинение и оправдание защо не се справя достатъчно добре. В сравне- ние с началото вече чува правилно голяма част от изолираните, звукове, срички и едносрични думи. Разбира по-добре речта на непознати хора при бавен и отчетлив говор. Все още има нужда от разяснения и повторения в отдени ситуации. В повечето случаи разпознаването на мъжки, женски и детски гласове е коректно. Добре познава гласовете на близки и познати хора на различно разстояние, използва телефон без притеснение. По-сериозните проблеми са все по-често проявената раздразнителност, избягване на ситуации, в които вземат участие повече от двама души и продължаващото желание за изолация. След провеждане на няколко последователни разговори отново се налага връщане на по-стара програма. Раздразненията според членове на семейството са се засилили в период на интензивно общуване с по-голям брой непознати лица и постоянното следене на всички разговори от страна на клиента. Наблюдава се нереалистично очакване от негова страна и това довежда до вербални изблици и изолация.

\section{Заключение}

Въпреки продължителната рехабилитация до този момент пациентът предпочита по-ниските нива на усилване (удължени периоди на преминаване към следваща по-силна програма), при всеки опит за преминаване към следваща програма съобщава за дразнене от околните звуци до степен на непоносимост. Наблюдава се повишена раздразнителност, конфликтност с близки хора, желание за усамотяване и изолация от обкръжаващата среда. В момента пациентът използва постоянно кохлеарния имплант на втора програма от направените втори настройки на процесора. За да може да общува с околните, все още си помага при разбирането на речта, като отчита по устните на говорещия.

Трябва да имаме предвид, че дори след продължително използване на кохлеарен имплант винаги се наблюдават трудности при локализацията на звука, наличие на ехо, правилно възприемане на речта при фонов шум, проследяване на разговор с няколко участници и други. 
Пациентите с кохлеарни импланти сравнително бързо се научават да чуват звуци, включително и тихи, но може да отнеме години, за да се научат да разбират речта, като в някои случаи дори и не успяват [4]. Неадекватните очаквания от страна на родители, близки и самите пациенти водят до разочарование, а в някои случаи дори до отказ от носене на импланта.
За съжаление редица „успешни“ имплантации у нас завършват с пълен отказ от ползването на устройствата, а при други освен усещането на звука (най-ниското стъпало на слуховите способности) не се отбелязва друг значителен прогрес.

\section{Литература}

1. Rouev P, Mumdzhiev H, Spiridonova J, Dimov P. Universal newborn hearing screening program in Bulgaria. Int. Journal P. Otorhinolaryngol. 2004;68(6):805-810.

2. Кацарска, В., М. Христова. 2006 - Книга за родителите на деца със слухови нарушения. София.

3. Балканска, Н. 2009, Кохлеарната имплантация в детска възраст- приложение, рехабилитация, обучение. София.

4. Copeland B. J. and H. C. Pillsbury, Cohlear Implantation for the Treatment of Deafness, Annu. Rev. Med. 2004.55:157-167. 